\title{
Synthesis of Bulk and Supported Molybdenum Carbide by a Single-Step Thermal Carburization Method
}

Hua-Min Wang, Xiao-Hui Wang, Ming-Hui Zhang, * Xiao-Yong Du, Wei Li, Ke-Yi

Tao

\section{Supporting Information}

\section{Preparation of 23 wt $\% \beta-\mathrm{Mo}_{2} \mathrm{C} / \gamma-\mathrm{Al}_{2} \mathrm{O}_{3}$ by the TPRe method}

The $\mathrm{MoO}_{3} / \gamma-\mathrm{Al}_{2} \mathrm{O}_{3}$ precursors were prepared by impregnation of $\gamma-\mathrm{Al}_{2} \mathrm{O}_{3}$ using aqueous solutions of $\left(\mathrm{NH}_{4}\right)_{6} \mathrm{Mo}_{7} \mathrm{O}_{24} \cdot 4 \mathrm{H}_{2} \mathrm{O}$, followed by airing overnight, drying for $3 \mathrm{~h}$ at $120{ }^{\circ} \mathrm{C}$, and calcinations at $500{ }^{\circ} \mathrm{C}$ for $5 \mathrm{~h}$ in air. The $\mathrm{MoO}_{3} / \mathrm{MCM} 41$ precursor was carburized under $20 \% \mathrm{CH}_{4} / \mathrm{H}_{2}$ (v/v) mixture at a VHSV (volume hourly space velocity) of $6000 \mathrm{~h}^{-1}$. The temperature of the carburization process was firstly increased at room temperature to $500{ }^{\circ} \mathrm{C}$ at the rate of $10{ }^{\circ} \mathrm{C} / \mathrm{min}$. Subsequently, the carburization was operated by the ramping rate of $1{ }^{\circ} \mathrm{C} / \mathrm{min}$ from $500{ }^{\circ} \mathrm{C}$ to $700{ }^{\circ} \mathrm{C}$, and kept at the final temperature for $1.5 \mathrm{~h}$. The system was cooled to room temperature in $\mathrm{H}_{2}$ flow and passivated overnight in flowing $1 \% \mathrm{O}_{2} / \mathrm{N}_{2}(\mathrm{v} / \mathrm{v})$ gas to avoid strong bulk oxidation. The $\beta-\mathrm{Mo}_{2} \mathrm{C} / \gamma-\mathrm{Al}_{2} \mathrm{O}_{3}$ catalyst with theoretical loadings of 23 wt $\% \beta-\mathrm{Mo}_{2} \mathrm{C}$ was prepared.

\section{Preparation of 23 wt $\% \gamma-\mathrm{Mo}_{2} \mathrm{~N} / \gamma-\mathrm{Al}_{2} \mathrm{O}_{3}$ by the HMT-based method}

The alumina-supported salt precursor was prepared by impregnation of $\gamma-\mathrm{Al}_{2} \mathrm{O}_{3}$ with an aqueous solution of $\left(\mathrm{NH}_{4}\right)_{6} \mathrm{Mo}_{7} \mathrm{O}_{24} \bullet 4 \mathrm{H}_{2} \mathrm{O}$ and HMT with a fixed mole ratio 1:2, which was obtained by dissolving the reagents in $15 \% \mathrm{NH}_{3} \cdot \mathrm{H}_{2} \mathrm{O}$ solution. The sample was then dried naturally for $48 \mathrm{~h}$ and dried at $80{ }^{\circ} \mathrm{C}$ for $6 \mathrm{~h}$. The precursor was heated at a rate of $10{ }^{\circ} \mathrm{C} \mathrm{min}^{-1}$ and kept at $650{ }^{\circ} \mathrm{C}$ for $2 \mathrm{~h}$ under a flow of argon. The product was cooled to room temperature under argon and passivated in a flow of $1 \%(\mathrm{v} / \mathrm{v})$ $\mathrm{O}_{2} / \mathrm{N}_{2}$. The $\gamma-\mathrm{Mo}_{2} \mathrm{~N} / \gamma-\mathrm{Al}_{2} \mathrm{O}_{3}$ catalyst with theoretical loadings of $23 \mathrm{wt} \% \gamma-\mathrm{Mo}_{2} \mathrm{~N}$ was prepared.

Preparation of 23 wt $\% \gamma-\mathrm{Mo}_{2} \mathrm{~N} / \gamma-\mathrm{Al}_{2} \mathrm{O}_{3}$ by the TPR method 
The $\mathrm{MoO}_{3} / \gamma-\mathrm{Al}_{2} \mathrm{O}_{3}$ precursors were prepared by impregnation of $\gamma-\mathrm{Al}_{2} \mathrm{O}_{3}$ using aqueous solutions of $\left(\mathrm{NH}_{4}\right)_{6} \mathrm{Mo}_{7} \mathrm{O}_{24} \cdot 4 \mathrm{H}_{2} \mathrm{O}$, followed by airing overnight, drying for $3 \mathrm{~h}$ at $120{ }^{\circ} \mathrm{C}$, and calcinations at $500{ }^{\circ} \mathrm{C}$ for $5 \mathrm{~h}$ in air. The $\mathrm{MoO}_{3} / \gamma-\mathrm{Al}_{2} \mathrm{O}_{3}$ precursor was then nitride to yield $\mathrm{Mo}_{2} \mathrm{~N} / \gamma-\mathrm{Al}_{2} \mathrm{O}_{3}$ catalyst. The flowing ammonia had a VHSV of $6000 \mathrm{~h}^{-1}$. The temperature was increased in two steps: rapidly from room temperature to $350{ }^{\circ} \mathrm{C}$ (at $6{ }^{\circ} \mathrm{C} / \mathrm{min}$ ), and then slowly from 350 to $650{ }^{\circ} \mathrm{C}$ (at $1{ }^{\circ} \mathrm{C} / \mathrm{min}$ ). The temperature was then held at $650{ }^{\circ} \mathrm{C}$ for $2 \mathrm{~h}$. The system was then cooled to room temperature in flowing $\mathrm{NH}_{3}$, and passivated overnight in flowing $1 \% \mathrm{O}_{2} / \mathrm{N}_{2}(\mathrm{v} / \mathrm{v})$ gas to avoid strong bulk oxidation. The $\gamma-\mathrm{Mo}_{2} \mathrm{~N} / \gamma-\mathrm{Al}_{2} \mathrm{O}_{3}$ catalyst with theoretical loadings of 23 wt $\% \gamma-\mathrm{Mo}_{2} \mathrm{~N}$ was prepared. 